\title{
Sustainability of Crop Production Under Changing Climate Pattern in the Chhattisgarh Region of Central India
}

\author{
A.S.R.A.S. Sastri, Diwakar Naidu and Ajay K. Srivastava \\ Indira Gandhi Agricultural University \\ Raipur (M.P.) - 492012 INDIA
}

\begin{abstract}
The Chhattisgarh region of Central India has an average annual rainfall of about 1400 $\mathrm{mm}$ and rice is the major crop grown mostly in rainfed conditions under 'broadcast biasi' system of cultivation. Out of the three agroclimatic zones (ACZs) in this region viz., i) Chhattisgarh Plains, ii) Bastar Plateau and iii) Northern Hills, the latter two ACZs are inhibited predominantly by native tribes.
\end{abstract}

There are some pockets in this region where rainfall is decreasing significantly during last 4-5 decades. Though the rainfall is decreasing the agrotechnology developed in the recent decades has increased the productivity of rice and other crops.

In this paper, the sustainability of the productivity of rice and other crops has been examined using the 'Sustainable Yield Index (SYI) which is :

$$
\mathbf{S Y I}=\frac{\mathbf{Y}-\sigma}{\mathbf{Y} \max }
$$

Where $\mathbf{Y}=$ Average productivity of a given crop under given management over time.

$\sigma=$ Standard deviation of the productivity of the data set.

$\mathbf{Y} \max =$ Highest productivity of the data set

In tradition bound and predominantly native tribal areas and with poor socioeconomic conditions, the agricultural inputs like chemical fertilizers, insecticides/pesticides etc., are very meager and hence the agricultural sustainability in these areas can be assessed from crop productivity and its variability.

In this paper the sustainability of the important crops is examined in view of the changing rainfall pattern. In unsustainable production areas, the causes for the unsustainable productivity are examined. Remedial measures for improving the productivity either through water harvesting or through crop diversification have been suggested.

Key Words : Sustainability, Climate Change, Crop Production Growth Rate. 


\section{Introduction}

The green revolution in India in the mid sixties created impressive achievements but bypassed the rainfed areas limiting the achievements to irrigated areas only.

In Chhattisgarh region of Madhya Pradesh State in Central India comprising 3 agroclimatic zones (Fig. 1) the productivity of rice very low $(1-1.5 \mathrm{t} / \mathrm{ha})$. With about $1400 \mathrm{~mm}$ of average annual rainfall of which about 90 percent is received during the SW monsoon season (June-September), rice is grown in about 3.8 million hectares mostly under rainfed conditions and by broadcast method of sowing and bushening (locally called biasi) about 30-40 days after sowing. Earlier studies (Baghel and Sastri, 1993; Sastri and Urkurkar, 1995) revealed that there is a significant decreasing trend of rainfall in some pockets of each of the 8 districts but, the productivity of rice has still increased due to technological developments

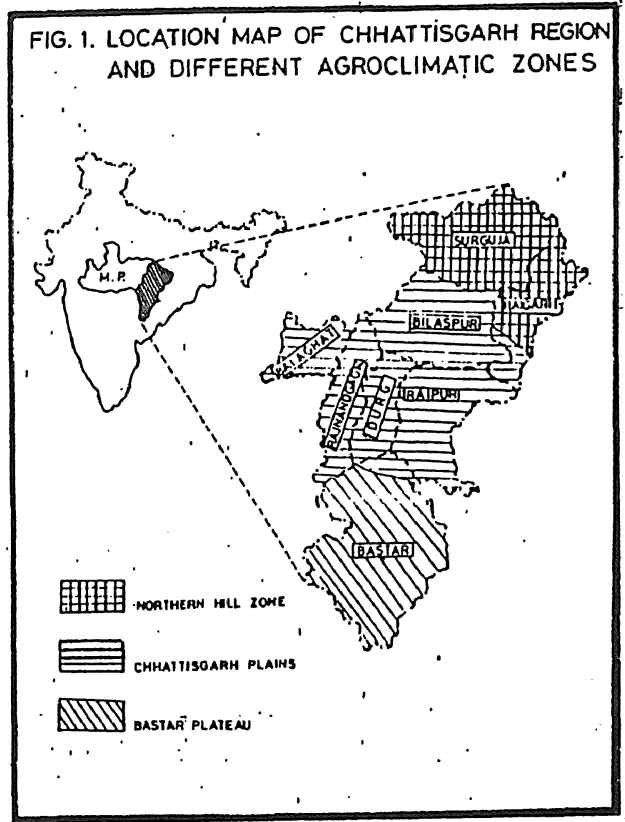
(Anonymous, 1996).

In this paper the changing rainfall pattern, the productivity and sustainability of rice and other crops for all the districts are discussed in detail.

\section{Area and Productivity trends of Different Crops in Chhattisgarh Region}

\section{i) Growth rates of area}

It can be seen from Table 1 that in Chhattisgarh plains highest growth rate of rice area was in respect of Raigarh while least in Bilaspur district during the study period of 197778 to $1991-92$.

In case of wheat, there are negative growth rates of area in all the districts of Chhattisgarh Plains and also in Bastar Plateau. In Northern Hills the growth rate of wheat is increasing at the rate of 3.66 percent per year. The negative growth rates of wheat in Chhattisgarh Plains are due to increasing winter season temperatures (Fig. 2).

The chickpea area is increasing in all the districts of Chhattisgarh Plains zone and Bastar Plateau and is decreasing in Northern Hills. In Chhattisgarh Plains zone, lathyrus (grass pea), is being replaced by chickpea. In Northern Hills zone, chickpea is being replaced by wheat. The linseed area is also decreasing in all the districts of Chhattisgarh Plains and Bastar Plateau zones while it is increasing in the Northern Hills. 


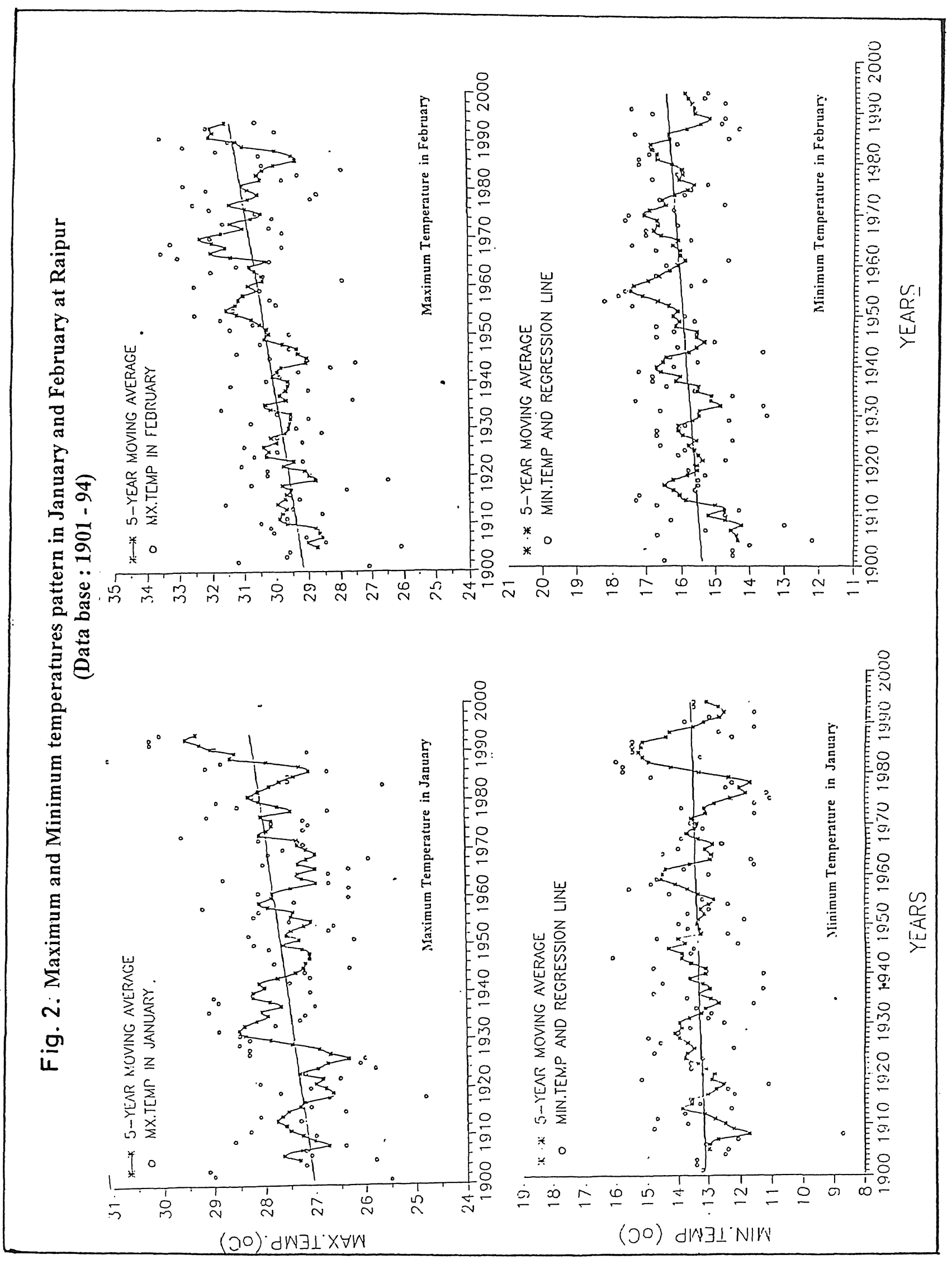


Table 1: Growth Rates (Percent/year) of the Area and Productivity of some important crops in different districts of Chhattisgarh region.

\begin{tabular}{|l|c|r|r|r|r|r|r|r|r|r|r|r|}
\hline Districts & \multicolumn{2}{|c|}{ Rice } & \multicolumn{2}{c|}{ Wheat } & \multicolumn{2}{c|}{ Chickpea } & \multicolumn{2}{c|}{ Groundnut } & \multicolumn{2}{c|}{ Linseed } & \multicolumn{2}{c|}{ Pigeonpea } \\
\hline & $\mathbf{A}$ & $\mathbf{P}$ & \multicolumn{1}{|c|}{$\mathbf{A}$} & $\mathbf{P}$ & \multicolumn{1}{|c|}{$\mathbf{A}$} & $\mathbf{P}$ & $\mathbf{A}$ & $\mathbf{P}$ & $\mathbf{A}$ & $\mathbf{P}$ & $\mathbf{A}$ & $\mathbf{P}$ \\
\hline Raipur & 0.56 & 3.63 & -1.18 & 2.87 & 15.45 & 1.93 & 1.77 & 2.79 & -8.17 & 6.68 & -2.24 & 2.61 \\
\hline Durg & 0.80 & 2.55 & -2.00 & 3.94 & 6.59 & 4.55 & 33.83 & 2.61 & -4.89 & 3.78 & -2.92 & 5.54 \\
\hline Rajanadgaon & 0.82 & 0.78 & -1.93 & 4.13 & 7.32 & 2.88 & 7.04 & 3.61 & -3.67 & 4.60 & -0.99 & 3.58 \\
\hline Bilaspur & 0.44 & 5.39 & -1.79 & 6.76 & 2.20 & 1.54 & 25.94 & 3.88 & 4.96 & 4.03 & -1.54 & 3.88 \\
\hline Raigarh & 1.18 & 2.38 & -6.47 & 4.73 & 0.0 & 1.77 & 4.57 & 4.36 & 4.57 & 3.21 & 0.43 & 3.12 \\
\hline Balaghat & 0.52 & 1.08 & 2.21 & 14.08 & 3.09 & 3.17 & -13.0 & 2.20 & -1.99 & 5.08 & 2.18 & 3.57 \\
\hline Chhattisgah Plains & 0.71 & 2.69 & -1.13 & 5.90 & 5.60 & 2.47 & 6.31 & 3.29 & -3.14 & 4.44 & -1.35 & 3.51 \\
\hline Bastar Plateau & 1.32 & 1.85 & -2.57 & 2.35 & 0.72 & 2.63 & - & - & -4.48 & 3.90 & 3.22 & 6.10 \\
\hline Northern Hills & 1.21 & 3.62 & 3.66 & 4.01 & -1.17 & 2.48 & 19.73 & 3.44 & 2.53 & 3.74 & 3.52 & 4.26 \\
\hline
\end{tabular}

\section{ii) Growth rates of productivity}

The productivity of all crops is increasing in all the 3 ACZs. In the Chhattisgarh Plains, with 6 districts, the range of the growth rates of productivity of different crops is as follows :

\begin{tabular}{|l|c|l|c|}
\hline Crop & $\begin{array}{c}\text { Range of growth rates of } \\
\text { productivity (percent/year) }\end{array}$ & Crop & $\begin{array}{c}\text { Range of growth rates of } \\
\text { productivity (percent/year) }\end{array}$ \\
\hline Rice & 0.78 to 5.39 & Groundnut & 2.20 to 4.36 \\
\hline Wheat & 2.87 to 14.08 & Linseed & 3.21 to 6.68 \\
\hline Chickpea & 1.54 to 4.55 & Pigeonpea & 2.61 to 5.54 \\
\hline
\end{tabular}

The regression equations of the area and productivity trends of some crops for the 3 ACZs given in Table 2. The decreasing trends of linseed and increasing trends of chickpea areas in Chhattisgarh Plains are highly significant while the increasing trend of wheat productivity is significant only in Chhattisgarh Plains zone. The increasing trends of the productivity of other crops are not significant in Chhattisgarh Plains.

Table 2: Regression equations of the trendlines of area and productivity of some important crops in the 3 agroclimatic zones.

\begin{tabular}{|l|l|l|l|l|}
\hline & \multicolumn{4}{|c|}{ Regression equations for the zone } \\
\hline Crop & & Chhattisgarh Plains & Bastar Plateau & Northern Hills \\
\hline Rice & Area & $\mathrm{Y}=443.5+3.25 \mathrm{X}(0.32)$ & $\mathrm{Y}=453.5+6.94 \mathrm{X}(0.92)^{* *}$ & $\mathrm{Y}=269.9+3.02 \times(0.90)^{* *}$ \\
& Prod. & $\mathrm{Y}=820.3+23.9 \mathrm{X}(0.27)$ & $\mathrm{Y}=752.5+16.4 \mathrm{X}(0.30)$ & $\mathrm{Y}=604.7+24.2 \times(0.28)$ \\
\hline Wheat & Area & $\mathrm{Y}=19.6-0.25 \mathrm{X}(0.18)$ & $\mathrm{Y}=3.3+0.07 \mathrm{X}(0.87)^{* *}$ & $\mathrm{Y}=12.5+0.57 \mathrm{X}(0.51)^{*}$ \\
& Prod & $\mathrm{Y}=461.5+52.6 \mathrm{X}(0.66)^{* *}$ & $\mathrm{Y}=888.1+24.7 \mathrm{X}(0.54)^{* *}$ & $\mathrm{Y}=690.8+34.4 \mathrm{X}(0.45)$ \\
\hline Pigeonpea & Area & $\mathrm{Y}=6.9-0.09 \mathrm{X}(0.37)$ & $\mathrm{Y}=1.9+0.06 \mathrm{X}(0.28)$ & $\mathrm{Y}=5.3+0.25 \mathrm{X}(0.69)^{* *}$ \\
& Prod. & $\mathrm{Y}=759.8+32.3 \mathrm{X}(0 . \quad)$ & $\mathrm{Y}=720.9+60.5 \mathrm{X}(0.45)$ & $\mathrm{Y}=798.7+43.1 \mathrm{X}(0.53)^{*}$ \\
\hline Linseed & Area & $\mathrm{Y}=223.0-8.95 \mathrm{X}(0.52)^{*}$ & $\mathrm{Y}=6.1+0.22 \mathrm{X}(0.68)^{* *}$ & $\mathrm{Y}=4.6+0.13 \mathrm{X}(0.24)$ \\
& Prod. & $\mathrm{Y}=114.2+6.67 \mathrm{X}(0.43)$ & $\mathrm{Y}=147.6+7.36 \mathrm{X}(0.65)^{* *}$ & $\mathrm{Y}=134.1+5.51 \mathrm{X}(0.26)$ \\
\hline Chickpea & Area & $\mathrm{Y}=15.8+1.38 \mathrm{X}(0.82)^{* *}$ & $\mathrm{Y}=2.0+0.02 \mathrm{X}(0.05)$ & $\mathrm{Y}=7.4+0.07 \mathrm{X}(0.04)$ \\
& Prod. & $\mathrm{Y}=407.7+11.6 \mathrm{X}(0.44)$ & $\mathrm{Y}=338.8+11.3 \mathrm{X}(0.52)^{* *}$ & $\mathrm{Y}=337.1+8.95 \mathrm{X}(0.39)$ \\
\hline
\end{tabular}


In Bastar Plateau, the increasing trend of rice and decreasing trends of wheat and linseed areas are highly significant. The increasing productivity trends of wheat, linseed and chickpea are significant while the increase of the productivity of other crops is not significant.

In the Northern Hills zone, the increase of rice, wheat and Pigeonpea area is significant and the same for other crops are not significant.

\section{Rainfall Pattern}

\section{i) Rainfall distribution}

Table 3 shows the average seasonal and annual rainfall and rainy days and their spatial variability of different districts in Chhattisgarh region.

Durg district has the lowest annual and seasonal (June to September) rainfall while the highest seasonal rainfall is in Raigarh district and highest annual rainfall is in the Bastar district. Durg has the lowest seasonal rainy days while Raipur has the lowest annual number of rainy days. The highest seasonal as well as annual number of rainy days are in Raigarh district. The highest variability of seasonal rainfall and rainy days is in Bastar district (1130-1637 $\mathrm{mm}$ ) while the highest variability of annual rainfall and least variability of rainy days are in Balaghat district. The highest variability of annual number of rainy days is in Raigarh district while the least variability is in Rajnandgaon district.

Table 3 : District wise seasonal (June-September) and annual rainfall and corresponding rainy days and their spatial variability.

\begin{tabular}{|l|c|c|c|c|c|c|c|c|}
\hline & \multicolumn{4}{|c|}{ Average district statistics } & \multicolumn{3}{c|}{ Spatial variability in each district } \\
\hline Districts & Seasonal Rainfall & \multicolumn{2}{|c|}{ Annual Rainfall } & Seasonal Rainfall & \multicolumn{2}{c|}{ Annual Rainfall } \\
\hline & $\begin{array}{c}\text { Rainfall } \\
(\mathrm{mm})\end{array}$ & $\begin{array}{c}\text { Rainy } \\
\text { Days }\end{array}$ & $\begin{array}{c}\text { Rainfall } \\
(\mathrm{mm})\end{array}$ & $\begin{array}{c}\text { Rainy } \\
\text { days }\end{array}$ & $\begin{array}{c}\text { Rainfall } \\
(\mathrm{mm})\end{array}$ & $\begin{array}{c}\text { Rainy } \\
\text { days }\end{array}$ & $\begin{array}{c}\text { Rainfall } \\
(\mathrm{mm})\end{array}$ & $\begin{array}{c}\text { Rainy } \\
\text { days }\end{array}$ \\
\hline Raipur & 1277.0 & 51 & 1384.9 & 62 & $1054-1385$ & $43-56$ & $1195-1549$ & $54-69$ \\
\hline Durg & 1020.4 & 50 & 1186.9 & 63 & $940-1264$ & $46-55$ & $1121-1359$ & $55-67$ \\
\hline R'gaon & 1021.8 & 52 & 1232.0 & 65 & $850-1142$ & $50-54$ & $1108-1332$ & $63-67$ \\
\hline Raigarh & 1413.6 & 63 & 1516.7 & 78 & $1268-1468$ & $55-65$ & $1445-1726$ & $68-92$ \\
\hline Bilaspur & 1219.3 & 58 & 1391.7 & 71 & $957-1403$ & $53-64$ & $1190-1544$ & $66-75$ \\
\hline Surguja & 1200.5 & 61 & 1493.2 & 76 & $1015-1262$ & $52-61$ & $1344-1657$ & $64-76$ \\
\hline Bastar & 1315.5 & 61 & 1532.2 & 76 & $1130-1637$ & $53-67$ & $1371-1788$ & $68-83$ \\
\hline Balaghat & 1277.7 & 59 & 1527.5 & 75 & $1212-1710$ & $57-64$ & $1392-1897$ & $67-76$ \\
\hline
\end{tabular}




\section{ii) Changing rainfall pattern}

Analysis of the historical rainfall data (1901-1990) of the district headquarters in Chhattisgarh region reveals that there is not much decreasing rainfall pattern in these districts. However, in Raipur district there are some pockets where there is significant decreasing pattern in annual rainfall (Fig. 3) indicating that the regional or micro-regional changes of rainfall are highly significant and are detrimental in crop production especially for rice.

\section{iii) Rainfall pattern and rice productivity :}

An analysis of the recent rainfall data (1971 onwards) revealed that the rainfall in recent two decades is decreasing almost in all districts. Though the rainfall is decreasing the productivity of rice is increasing with higher gradients in Raipur, Bilaspur and Balaghat districts due to development of irrigation in Raipur and Bilaspur districts and due to higher quantum and stable rainfall in Balaghat district.

In Bastar and Surguja, the predominantly native tribal population districts, the increase of rice productivity is negligible, though the quantum of rainfall is still higher than in other districts. This is due to negligible use of inputs and hence there is a great potential to increase the productivity.

\section{Sustainability}

\section{i) Concepts of sustainability}

According to UNEP, the sustainable development is defined as improving the quality of human life while living within the carrying capacity of supporting ecosystems'. The agricultural sustainability according to FAO (1989) is that sustainable agriculture should involve the successful management of resources for agriculture to satisfy changing human needs while maintaining or enhancing the quality of environment and conserving the natural resources'. Edwards (1987) defined sustainable agriculture as integrated systems of agriculture production that are less dependent on high inputs of energy and synthetic chemicals and are more dependent on intensive management rather than conventional monoculture systems'.

\section{ii) Sustainable yield index (SYI)}

All the concepts of sustainability now in vogue, point out that sustainable agriculture is one which makes use of low cost inputs, less chemical fertilizers, maintain soil fertility and ecological harmony. Most often sustainability is considered in qualitative terms only. Singh et. al. (1990) tried to quantify sustainability using the 'Sustainable Yield Index' (SYI) given as : 


\section{Fig. 3: Trends of annual rainfall at different stations in Raipur district.}
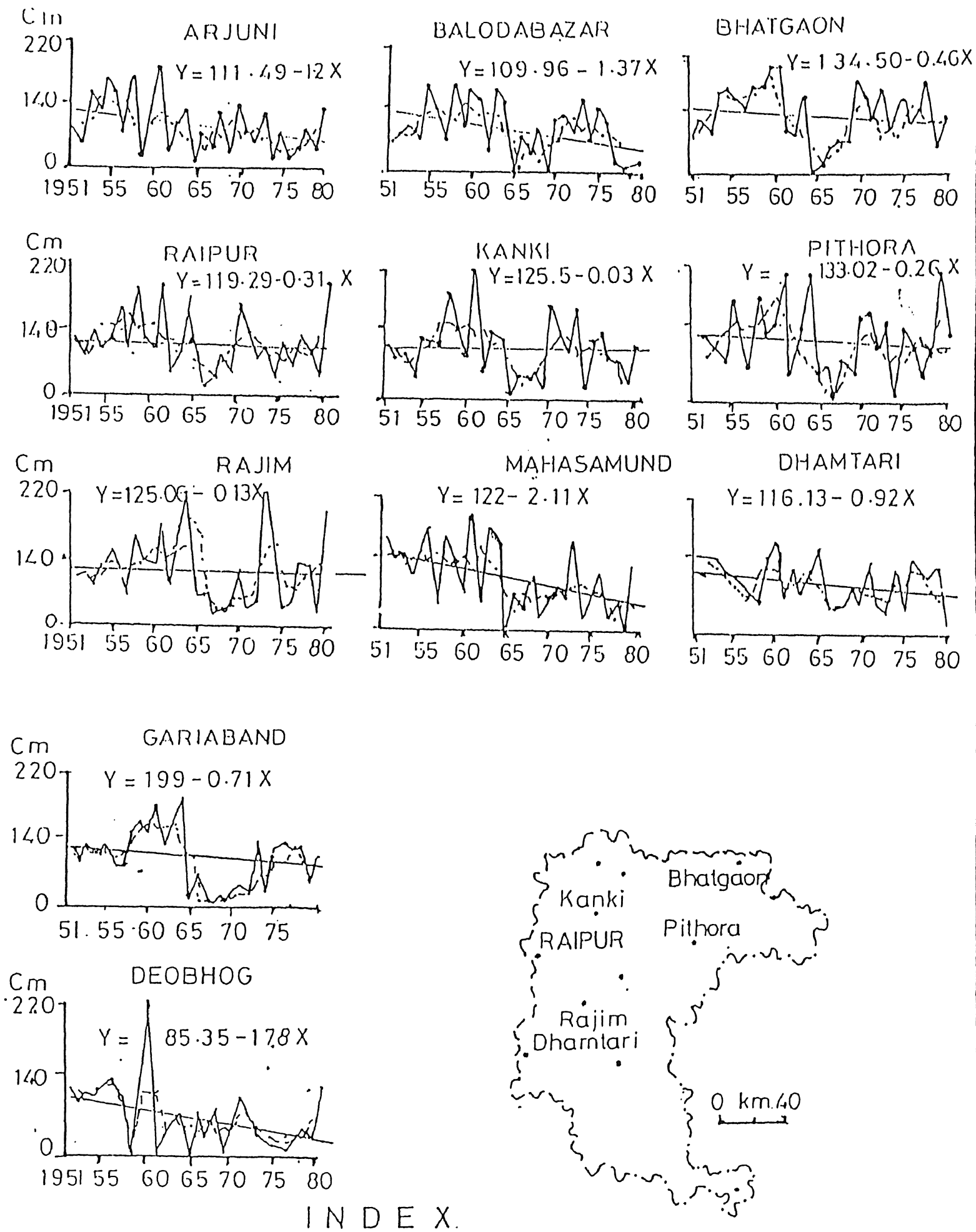

$\longrightarrow$ ACTUAL ANNUAL

....-. RUNNING MEAN

- REGRESSION LINE 


$$
\text { SYI }=\frac{\mathbf{Y}-\sigma}{\mathbf{Y} \max }
$$

Where $Y=$ Average productivity of a given crop under given management over time.

$\sigma=$ Standard deviation of the productivity of the data set.

$Y \max =$ Highest productivity of the data set

The sustainable yield indices (SYI) of all major crops are computed using the data from 1977-78 to 1992-93. Using the SYI, the sustainability of the productivity of these crops is quantified as using the following criterion :

\begin{tabular}{|c|c|}
\hline SYI range & Sustainability \\
\hline Grater than 0.7 & Highly Sustainable (HS) \\
\hline 0.7 to 0.5 & Sustainable (S) \\
\hline 0.5 to 0.3 & Unsustainable (U) \\
\hline Less than 0.3 & Highly Unsustainable (HU) \\
\hline
\end{tabular}

Using the above criterion, the sustainability of the productivity of some important crops has been examined as shown in Table 4.

Table 4: Sustainable Yield Indices and the status of different crops in 3 agroclimatic zones of Chhattisgarh region.

\begin{tabular}{|c|c|c|c|c|c|c|}
\hline & \multicolumn{6}{|c|}{ Agroclimatic Zones } \\
\hline Crop & \multicolumn{2}{|c|}{ Chhattisgarh Plains } & \multicolumn{2}{|c|}{ Bastar Plateau } & \multicolumn{2}{c|}{ Northern Hills } \\
\hline & SYI & Status & SYI & Status & SYI & Status \\
\hline Rice & 0.63 & S & 0.73 & HS & 0.48 & U \\
\hline Small Millets & - & - & 0.62 & S & 0.41 & U \\
\hline Wheat & 0.38 & U & 0.66 & S & 0.58 & S \\
\hline Groundnut & 0.62 & S & - & - & 0.61 & S \\
\hline Chickpea & 0.67 & S & 0.63 & S & 0.71 & HS \\
\hline Lathyrus & 0.36 & U & - & - & - & - \\
\hline Linseed & 0.50 & S/U & 0.60 & S & 0.46 & U \\
\hline Pigeonpea & 0.55 & S & 0.47 & U & 0.56 & S \\
\hline Maize & - & - & 0.55 & S & 0.54 & S \\
\hline Mustard & 0.58 & S & - & - & - & - \\
\hline Soybean & 0.74 & HS & - & - & - & - \\
\hline
\end{tabular}

The productivity of wheat, lathyrus in Chhattisgarh Plains, pigeonpea in Bastar Plateau and rice, small millets and linseed in Northern Hills are unsustainable. The rice productivity in Bastar Plateau, chickpea productivity in Northern Hills and soybean productivity in Chhattisgarh Plains are highly sustainable. The productivity of linseed in Chhattisgarh Plains is in the border of sustainable and unsustainable productivity levels. 
The causes of low sustainability are either low average productivity or high standard deviation (higher fluctuations) or both. The maximum yield is the productivity potential of that crop using a given management.

To minimize the yield gap and variability, it is necessary to critically examine the causes of low productivity and high variability. For example, one of the causes of low productivity of rice in this region is the low plant population after biasi or bushening operation. The cause of high variability in respect of wet season crops like rice, small millets, maize, pigeonpea is the high rainfall variability and for winter crops like wheat, mustard, chickpea etc., higher fluctuations of temperatures are responsible for unsustainability. For crops like linseed and lathyrus, which are usually grown as relay crops in rice, rainfall in the initial stages and temperature in later stages are responsible for higher productivity fluctuations.

\section{Conclusions}

It has been found that there are varying trends of the areas and productivity of different crops in the 3 agroclimatic zones (ACZs). It was observed that there is decreasing rainfall in some pockets of some districts. Such trends are not discernible at district level. However, the rainfall in the last two decades is decreasing at all districts. But the rice productivity for the corresponding period is increasing due to technological development.

The productivity of a few crops in the $3 \mathrm{ACZs}$ is unsustainable. The reasons of the low sustainability are either low average productivity or high variability or both. The causes of low productivity for rice are low plant population and intermittent drought in wet season and changing temperature in winter season.

Technologies like providing life saving irrigation through farm-ponds for alleviation of drought and diversification crops in unproductive areas are being developed. The increasing area of soybean crop as a substitute for small millets is an example of the efforts of crop diversification and the soybean productivity is highly sustainable in this area.

\section{References :}

Anommous 1996. "Impact of National Agricultural Research Project on the agricultural development in Eastern Madhya Pradesh “. Indira Gandhi Agricultural Univ., Raipur, India, 107 p.

Baghel, S.S. and Sastri A.S.R.A.S., 1993. "Regional climate change and its influence on agriculture - A case study for Chhattisgarh region of Madhya Pradesh'. Proc. First Agricultural Science Congress - 1992, National Academy of Agricultural Science, New Delhi, India, 213-222. 
Edwards, C.A., 1987. 'The concept of integrated systems in lower input/sustainable agriculture'. American J. of Alternative Agric., 2, 148-152.

F.A.O. 1989, 'Sustainable agriculture production : Implications for international agriculture research'. FAO Res. and Tech. paper, 4, Rome, $131 \mathrm{p}$.

Sastri A.S.R.A.S. and Urkurkar, J.S.1995. 'Climatic variability and crop productivity - A case study for Chhattisgarh region of Central India'. Workshop on 'Impact of Climate Variability on Agricultural Productivity in South Asia region'. (South Asian START Regional Research Committee). IISc, Bangalore, India, 8-11 Feb. 1995.

Singh R.P., Das S.K., Bhaskara Rao and Reddy M.N., 1990. 'Towards Sustainable Dryland Agriculture Practices'. Central Research Institute for Dryland Agriculture, Hyderabad, India, 106 p. 